\title{
Reformulation of Corporate Criminal Sanction in the Mining Business Activities
}

\author{
Idris Wasahua \\ Faculty of Law \\ Esa Unggul University \\ Jakarta, Indonesia \\ idriswasahualegal@gmail.com
}

\begin{abstract}
This paper aims to analyze how the regulation of corporate criminal sanctions in the current mining sector. This is because corporate criminal sanctions in the mining sector are regulated in various laws differently. In addition, it will also be analyzed how the current corporate criminal sanctions have functional relationships in preventing recurrence of noncriminal acts by actors in mining business activities. From the results of the study, it was found that; First, corporate criminal sanctions in the field of mining other than those stipulated in laws that specifically regulate mining business such as mineral and coal mining laws, and oil and gas law, are also regulated in laws relating to business mining such as the law on protection and environmental management, the law on forestry, and laws on the prevention and eradication of forest destruction. Secondly, the current corporate criminal sanctions have not functioned optimally to prevent a repeat of the corporation's non-criminal mines. Thus, it still allows the perpetrators of corporate crime to repeat their actions. For that reason, it is necessary to formulate a corporate criminal sanction policy in the mining sector that serves to prevent the perpetrators from repeating their actions. The formulation policy is carried out by maximizing criminal sanctions already existing in the Criminal Code, by adding additional criminal sanctions in the form of revocation of certain rights as regulated in Article 10 letter a 1e and Article 35 paragraph 1 6e of the Criminal Code, on the right to run a certain livelihood, with a prohibition for the perpetrator of a corporate crime to not become a shareholder, a manager, or a party engaged in a corporation engaged in a mining business within a certain period of time.
\end{abstract}

Keywords - reformulation, corporate criminal sanctions, mining business.

\section{INTRODUCTION}

Mining business activities $[1]^{1}$ have high economic value for improving the economic welfare of the people, as well as the increase of State financial income. On the other hand, mining business activities also have a high risk that can cause negative implications that are multidemensional. Therefore, the parties involved in mining business activities must have high competence and integrity, meet strict requirements, and have a commitment to comply with various regulations related to mining business activities. The

\footnotetext{
1 The scope of mining includes general mining, and oil and gas mining. General mining is mining excavation material outside oil and gas. General mining is classified into five groups, namely; Firstly, radioactive mineral mining; Secondly, logical mineral mining; Third, non logical mineral mining; and Fourth, coal mining, peat, and bituminous solid, and Fifth, geothermal mining
}

rise of violation of criminal law in mining business activity becomes empirical evidence of lack of legal compliance of mining business actors. Ironically, the violation of criminal law is not only perpetrators committed for and on behalf of the person. However, it is also conducted for and on behalf of the corporation. Criminal acts committed by corporation is then known as a corporate crime. Marshall B. Clinard and Peter C. Yeager as quoted by H. Setiyono provide the notion of corporate crime as follows:

" A corporate crime is any act commited by corporations that is punished by the state, regardless of wether it is punished under administrative, evil, or criminal law"[2]

In the Supreme Court Regulation Number 13 Year 2016 on Criminal Acts by Corporations, in Article 1 point 8 mentioned:

"Corruption by Corporations is a criminal offense for which corporal liability may be required to the corporation in accordance with laws governing the corporation." [3]

Corporate criminal acts which may be imposed on mining business actors, not limited to laws that are specifically related to mining business activities, such as the law on mineral and coal mining, and the law on oil and natural gas. However, including other laws, such as forestry laws, and laws on environmental protection and management. Although, in the legislation relating to mining business activities, regulated on corporate criminal sanctions. However, the criminal sanctions have not seen a significant effect in preventing the repeat of corporate crime in mining business activities.

The corporate criminal sanctions in the current mining business include, among others; First, the basic penalty is; imprisonment, and fine penalties. Second, additional criminal form; revocation of business permit, deprivation of legal entity/business entity, seizure of goods used in committing a criminal act, confiscation of profits derived from a criminal offense, liability to pay the costs incurred as a result of a crime, and firm placement under the ability. To provide a deterrent effect for corporate criminal actors in mining business in order not to repeat their actions, it is necessary to formulate policy on the norms of corporate criminal sanctions. For that, the legal issues to be discussed in this paper are; First, what are the types of corporate criminal sanctions in mining business activities ?. Second, 
what is the formulation policy of corporate criminal sanction in mining business activity?

\section{DISCUSSION}

\section{A. Type of corporation criminal sanction in mining business activity}

Corporate criminal sanctions in mining business activities are not only regulated in laws that are directly related to the business of increase activity, such as Law Number 4 Year 2009 regarding Mineral and Coal Mining, and Law Number 22 Year 2001 regarding Oil and Natural gas. However, it is also regulated in other laws that are related to mining business activities. The arrangement of types of criminal sanctions in the law varies as stated below:

1) Laws that are directly related to mining business activities

1. Law Number 22 Year 2001 regarding Oil and Natural Gas, including: Criminal penalties, in the form of criminal penalties, and additional criminal, in the form of revocation of rights or appropriation of goods used for or obtained from criminal offenses in the business of Oil and Gas.

2. Law No. 4 of 2009 on Mineral and Coal Mining, including: Criminal penalty in the form of imprisonment and fine. Additional criminal consists of; Revocation of business license, and / or revocation of legal entity status, Deprivation of goods used in committing a criminal act, Deprivation of profits derived from a crime; and / or, the obligation to pay the costs incurred as a result of a crime.

3. Law No. 21 of 2014 on Geothermal, including: Criminal punishment in the form of imprisonment and fine. Additional criminal in the form of: Deprivation of goods used in committing a crime, Deprivation of profits derived from criminal acts and / or, obligations to pay the costs incurred due to crime.

2) Laws that are not directly related to mining business activities

1. Law Number 32 Year 2009 on the Protection and Management of the Environment, including: Criminal punishment in the form of imprisonment and fine. Additional punishment or disciplinary action in the form of: Deprivation of profits derived from a criminal offense, Closing all or part of the place of business and / or activity, Improvement due to a criminal offense, Liability to do what is neglected without rights and / or, Company placement under the maximum 3 (three) years.

2. Law Number 41 Year 1999 on Forestry, including: Criminal punishment in the form of imprisonment and fine.

3. Law Number 18 Year 2013 on Prevention and Eradication of Forest Destruction, consisting of: Criminal principal in the form of; imprisonment and fine. Criminal penalty in the form of closure of all or part of the company.

\section{B. Criminal sanctions formulation policy of corporation in} business activity pertambagan

In the Black Law Dictionary, Brya A. Garner, as quoted by $\mathrm{M}$. Ali Zaidan, states that criminal policy is a branch of criminal law related to crime protection (the branch of criminal science non cerned with protecting against crime).[4] Criminal law policy has a very important role as an alternative solution in overcoming the problems associated with the problem of crime prevention. Therefore, knowledge of criminal law reform is also very necessary. In this connection, Senna and Siegel said: "In addition to having some understanding of the law, the definition of crime, the various legal classification, and criminal responsibility, it is also important to recognize the need for criminal law reform"[5]

Therefore, the rules of criminal law, especially regarding the prevailing criminal sanctions, are constantly being scrutinized for their function in the prevention of a crime in order to achieve the objective of the crime itself. In general, the theory of the purpose of punishment can be grouped into three classes. First, absolute theory or retaliation theory (vergeldings theorien). Second, relative theory or goal theory (doel theorien). Third, the combined theory (vernegings theorien). The types of criminal sanctions set out in Article 10 of the Criminal Code include additional criminal and additional criminal charges. The principal punishment consists of capital punishment, imprisonment, imprisonment, fine penalty, and criminal cover. Whereas, additional criminal consists of removal of certain rights, confiscation of certain goods, and announcement of judge's verdict. This type of criminal sanction also applies to the provisions of the law outside the Criminal Code which governs criminal offenses, unless the law regulates other. [6]

Special additional criminal sanctions in the form of revocation of certain rights are regulated in Article 35 of the Criminal Code which consists of: a. the right to hold office in general or certain positions, b. right to enter the Armed Forces, c. the right to vote and be elected in elections held under general rules, $d$. the right to be a legal counselor or administrator on the determination of the court, the right to be a guardian, guardian, supervisor or supervisor, on a person who is not his or her own, e. the right to exercise the authority of the father, to exercise guardianship or abilities of his own children, and $f$. the right to run a certain search. According to Jan Remmelink, such criminal sanctions are intended because of the misuse of the work done. The imposition of sanctions in disciplinary form, such as the deprivation of the right to a profession during a certain period of time due to negligence or carelessness will provide great benefits[7]. Those who are deprived of their rights do not deserve the rights because their acts have been abused by committing a violation of the law[8].

Supposedly, the managers of corporations in the mining business, in addition to having competence in the management of mining business, must also have high integrity, and have a strong commitment to comply with various regulations related to mining business activities. Persons trusted to manage corporations in mining business activities, as much as possible to act professionally in good faith based on the principles of good corporate 
governance $[9]^{2}$. This is necessary, because mining business activities have a high risk that can cause negative implications multidimensional. The managers or administrators of the corporation as much as possible seek to avoid corporations and corporate crime. Therefore, when a corporation commits a criminal offense in a mining business activity, such corporate action is in addition to a violation of the criminal law norm, at the same time the corporation has also violated the principles of good corporate government. Ironically, even though the perpetrators of the criminal act in the mining corporation have been punished, the perpetrator can still repeat his actions.

Therefore, there is a need for corporate criminal sanction that works optimally to prevent the perpetrators of corporate crime to repeat their actions. On the other hand, the types of criminal sanctions, both the principal and the additional criminal to the perpetrators of corporate crime in the current mining business activities, according to the writer's opinion does not have a direct correlation in the effort to prevent the recurrence of criminal acts committed. In other words, even though the perpetrators of corporate crime have been sentenced to criminal law, the perpetrator still has the potential to repeat the crime. Therefore, it is necessary to formulate policies on the rules of criminal sanctions for the perpetrators of corporate crime which limit the movement of perpetrators so as not to repeat their criminal acts. The formulation policy of criminal sanction can be done by maximizing the criminal sanction already existing in the Criminal Code by adding additional criminal sanction in the form of revocation of certain rights as regulated in the Criminal Code, Article 10 letter a 1e and Article 35 paragraph $16 \mathrm{e}$, specific livelihoods into legislation related to mining business activities. Revocation of the right to run a certain livelihood is a prohibition for the perpetrator of a corporate crime in a mining business activity not to act as a shareholder, to become an administrator, or a party involved in a corporation engaged in mining business activities within a certain period of time. Through such sanctions, it is expected to prevent the perpetrator re-repeat his actions. It also serves as a basis for the application of additional criminal sanctions in the form of revocation of certain rights set forth in the Criminal Code. In this regard, Roeslan Saleh said that the entry of certain rights in the Criminal Code was revoked because the legislator considered the additional penalty to be appropriate. Suffering is not to want to eliminate someone's honor, but for other reasons such as special precautions. For example, revocation of a person's right becomes a doctor because of malpractice. The intention of revocation of the right is that no such crime shall be committed by the person concerned[10].

Sanctions for the revocation of certain rights set forth in Article 10 letter $b, 1 e$ of the Criminal Code in relation to the theory of the purpose of crime, including in relative theory or objective theory of special precautions. According to the special prevention theory, the purpose of punishment is to prevent perpetrators of crimes who have been convicted in

\footnotetext{
2 One theory related to Corporate Governance is Stewardship Theory. This theory is built on the philosophy of human nature that is essentially trustworthy, capable of acting with full responsibility, having integrity and being honest with others. Such a condition creates a fiduciary relationship (fiduciary relationship) desired by shareholders. In other words, Stewardship theory views management as a credible party to act best for shareholders, as well as the interests of stakeholders
}

order not to repeat their actions. This goal can be achieved, among others, by making the culprit become helpless[10].

\section{CONCLUSIONS AND RECOMMENDATIONS}

\section{A. Conclusion}

Criminal penalties applicable to corpoaration consist of; First, the principal penalty includes, imprisonment and fine penalty. Second, additional criminal form;revocation of rights or confiscation of goods used for or derived from criminal offenses in Oil and Gas business activities, revocation of business licenses, and / or revocation of legal entity status, confiscation of goods used in committing a criminal act, appropriation of profits derived from a criminal offense ; and / or, the obligation to pay any costs incurred by a crime, the closure of all or any part of the place of business and / or activity, reparations resulting from a crime, the duty of doing what is neglected without right; and / or, the placement of the company under the maximum of 3 (three) years. The criminal sanction is not yet functioning optimally in preventing the recurrence of corporate crime in mining business activities. Therefore, a formulation policy on corporate criminal sanctions is required, in particular, additional penalties for the perpetrator of a corporate crime not to become a shareholder, manager or a party involved in a corporation engaged in a mining business within a certain period of time.

\section{B. Recommendations}

The legislature may consider reformulating the corporate criminal sanctions in the mining business activities as mentioned in the above conclusions.

\section{REFERENCES}

[1] H. S. HS, Mining Law in Indonesia. Jakarta: PT Rajawali Press, 2008

[2] H. Setiyono, Corporate Crime, Viktimological Analysis and Corporate Accountability in Indonesian Penal Code. Malang: Bayumedia Publishing, 2005.

[3] State Gazette of the Republic of Indonesia Year 2016 Number 2058. .

[4] M. A. Zaidan, Criminal Policy. Jakarta: Sinar Grafika, 2016.

[5] S. and Siegel, Introduction to Criminal Justice. United State of Amereca, 1981

[6] A. A. Z. Abidin and A. Hamzah, Indonesian Penal Code. Jakarta: PT Yarsif Watampone, 2010.

[7] J. Rammelink, Criminal Law, Commentary on the Most Important Articles of the Dutch Criminal Code and Their Matches in the Indonesian Criminal Code. Jakarta: PT Gramedia Pustaka Utama, 2003.

[8] P. A. F. Lamintang, Penitensier Law of Indonesia. Bandung: CV Arimco, 1984.

[9] T. Budiyono, Company Law. Salatiga: Griya Media, 2011.

[10] A. Chazawi, Criminal Law Study, Criminal Stelsel, Criminal Acts, Criminal Theory and Limitations of Criminal Law Part 1. Raja Grafindo Persada, 2005. 